\title{
FESTIVE FOOD BRANDS AWARENESS AMONG YOUNG PEOPLE ON ROMANIAN MARKET
}

\author{
Laura Cătălina Ţimiraş, \\ "Vasile Alecsandri" University of Bacau, \\ timiras.laura@ub.ro
}

\begin{abstract}
In this paper are presented some of the results obtained through an exploratory research carried out in the month of April 2016 on a sample of 100 students from the Vasile Alecsandri University of Bacau, referring to awareness of festive food brands on the Romanian market. Festive products bave special sensory properties designed to especially satisfy gastronomic indulgence and not nutritional needs of individuals. Thus, we studied a number of categories covering mainly food products for the pleasure of eating, namely: confectionery, coffee, tea, chips and snacks, soft drinks and alcoholic beverages. Thus there are shown brands that enjoy the highest spontaneous awareness in the investigated sample, young people undergoing investigation being asked to indicate the top 3 brands that come to mind for various product categories investigated. The study shows both the brands which enjoy the highest top of mind awareness and those brands which were nominated by most respondents among the top three of which they remember.
\end{abstract}

Keywords

brand, unassisted awareness, top of mind awareness, festive foods, Romanian market

\section{JEL Classification}

M31

\section{Introduction}

Nowadays consumers have more options in terms of product choice, but much less time making decisions than they ever had, so a brand that helps simplify decisions, reduce risk purchase, create and provide expectations is invaluable ( Pike, 2008).

Regarding the choice of a product, Lehman et. al (1998) indicated a number of factors that may cause or precede the choice process, product / brand awareness being one of them (along with: awareness and liking of advertising, knowledge / understanding of the brand, perception / rating on specific attributes, importance of product attributes, satisfaction with present product, perceived risk in using the product, approach used to make a choise).

Most studies on brand aimed to evaluate brand equity, a concept that covers all positive and negative attributes from a consumer or organization point of view (Datculescu, 2012). Awareness is one of the attributes that underpin "brand equity", along with: brand loyalty, perceived quality, brand associations in addition to perceived quality, other proprietary brand assets: patents, trademarks, channel relationships etc. " (Kumar et. al, 1999).

The concept of "brand equity" is not universally accepted, but regardless of the opinions of experts on this subject, marketing research is frecvently focused on studying the performance of the brand and levers of action on it. In the evaluation of the performance of the brand, usually, awareness is one of the aspects covered by the studies, along with: knowledge of brand, the general opinion about it, functional efficiency of the product, image, feelings and emotional states evoked, the extent to which influences behavior. (Datculescu, 2012). 
Awareness is a quantitative component of the image and refers to the specified share of members from a population who have heard of brand, organization, product or person (Zaharia, 2003). By developing brand awareness, marketers pursue that at any time the need arises for a particular product / product category, brand will be activated from memory and will be taken into account in the choice of decision alternatives (Peter and Olson, 2008).

The awareness should not be confused with the favorable attitude towards the brand, in practice being situations where a brand is very well known because of some negative attributes. A study conducted in Romania, among students, with reference also to food products, showed that overall awareness of the products is associated with a higher quality (Voinea, 2013).

According to Dictionary of Agromarketing, festive or elite foods are intended for consumption with special occasions (religious holidays, birthdays, etc.) or, in many cases, they are purchased as gifts. The main features that these products have to submit refers to the outstanding sensory properties and very good image among potential buyers, due, on the one hand, to the properties of the product, on the other hand, to pricing strategy practiced by the producing company (usually high), messages and systems of communication associated with the product on the market, distribution systems practiced (often selective) (Marian, 2016). Festive products contain substances which consumed in large quantities can be harmful (fats, sugars, alcohol, caffeine etc.). Through research was assessed spontaneous awareness of different brands on the Romanian market. We asked respondents to indicate the top 3 brands for each category of food products which were the subject of the study, products with specific characteristics (distinctive organoleptic characteristics, containing substances that can be harmful in frequently consumption) which falls into the category of festive: confectionery (excluding chocolate), chocolate, coffee, tea, chips and snacks, soft drinks and alcoholic beverages.

\section{Research methodology}

The survey was conducted in April 2016 on a sample of 100 young people, aged 1830, students of the Faculty of Economic Sciences of the Vasile Alecsandri University of Bacau. Data collection was conducted through self-registration. Research has an exploratory nature.

Each brand was evaluated for top of mind awareness (the percentage of respondents who indicated that brand the first among those remembered) and in terms of the percentage of respondents who indicated that brand between the (maximum) three nominees.

Results show awareness for the brands which have been nominated by at least five respondents of the one hundred investigated.

\section{Research results}

In the category confectioneries (except chocolate), ranked first, both in terms of the number of people who indicated first and in terms of position among the top known brands, is Milka. There is an appreciable "distance" between this brand and the following brands in the hierarchy; thus, more than $50 \%$ of respondents indicated in the top three known brands Milka compared with Oreo, located in the second place from this point of view. Also, as the first nomination, Milka exceeded over two times the brands ranked second (Oreo, Joy and Nestlé). Among the ten brands nominated by a minimum of 5 respondents, we can find local brands such as Poiana and Rom.

Only $46 \%$ of all respondents indicated three brands in this product category, $9 \%$ only two brands and $24 \%$ one brand. A relatively large number of respondents $(21 \%)$ indicated no brand on this product category. 
Table no. 1 The most popular* brands of confectionery (excluding chocolate) on the Romanian market

\begin{tabular}{|c|c|c|c|c|}
\hline \multirow[b]{2}{*}{ Brand } & \multicolumn{3}{|c|}{$\begin{array}{l}\text { Share of respondents who indicated a particular } \\
\text { brand among the top three that come to mind }\end{array}$} & \multirow{2}{*}{$\begin{array}{l}\text { \% persons who } \\
\text { indicated brand } \\
\text { among the top } 3 \\
\text { known brands in total } \\
\text { number of } \\
\text { respondents }\end{array}$} \\
\hline & $\begin{array}{l}\text { As first } \\
\text { option }\end{array}$ & $\begin{array}{l}\text { As second } \\
\text { option }\end{array}$ & As third option & \\
\hline Milka & 14 & 5 & - & 19 \\
\hline Oreo & 6 & 3 & 3 & 12 \\
\hline Bucuria & 6 & 3 & 1 & 10 \\
\hline Raffaello & 1 & 5 & 4 & 10 \\
\hline Poiana & 1 & 6 & 2 & 9 \\
\hline Rom & 5 & 1 & 3 & 9 \\
\hline Kinder & 5 & 3 & - & 8 \\
\hline 7 Days & - & 4 & 4 & 8 \\
\hline Nestlé & 6 & - & 1 & 7 \\
\hline Snickers & 2 & 3 & 1 & 6 \\
\hline Other answers & 33 & 22 & 27 & $\mathrm{X}$ \\
\hline Total & 79 & 55 & 46 & $\mathrm{X}$ \\
\hline
\end{tabular}

* brands indicated by a minimum 5 respondents.

Source: own computation

The highest degree of knowledge of brands (compared to other product categories analyzed) enjoy chocolate. Thus, only one respondent indicated no brand, while $72 \%$ indicated three brands, $22 \%$ two brands and 5\% one brand. The first in the top of mind and in terms of the first three nominated are Milka and Poiana. Thus, in regard to the first nominee, $48 \%$ of respondents indicated Milka and 23\% Poiana. Over $70 \%$ of respondents indicated Milka and 57\% Poiana among the top three brands that come to mind. Of the ten brands presented in Table. 2, which were nominated by at least 5 respondents, over 50\% are represented by domestic brands (Poiana, Africana, Primola, Laura, Kandia, Rom).

Table no. 2 The most popular* brands of chocolate on the Romanian market

\begin{tabular}{|l|c|c|c|c|}
\hline \multirow{2}{*}{ Brand } & \multicolumn{2}{|c|}{$\begin{array}{c}\text { Share of respondents who indicated a } \\
\text { particular brand among the top three that come } \\
\text { to mind }\end{array}$} & $\begin{array}{c}\text { \% persons who } \\
\text { indicated brand } \\
\text { among the top 3 } \\
\text { known brands in } \\
\text { total number of } \\
\text { respondents }\end{array}$ \\
\cline { 2 - 5 } & $\begin{array}{c}\text { As first } \\
\text { option }\end{array}$ & $\begin{array}{c}\text { As second } \\
\text { option }\end{array}$ & As third option & 71 \\
\hline Milka & 48 & 19 & 4 & 57 \\
\hline Poiana & 23 & 22 & 12 & 22 \\
\hline Africana & 2 & 10 & 10 & 19 \\
\hline Primola & 3 & 9 & 7 & 18 \\
\hline Laura & 3 & 8 & 7 & 12 \\
\hline Kandia & 5 & 1 & 6 & 10 \\
\hline Bucuria & 6 & 4 & & 9 \\
\hline Heidi & 2 & 6 & 3 & 6 \\
\hline Rom & 1 & 5 & 2 & $X$ \\
\hline Kinder & 5 & 8 & 3 & $X$ \\
\hline Other answers & 99 & 94 & 72 & \\
\hline Total & 2 & 2 & 18 & \\
\hline
\end{tabular}

* brands indicated by a minimum 5 respondents. Source: own computation 
Regarding coffee, Jacobs brand stand out much from other brands, with $38 \%$ value for top of mind and $68 \%$ of respondents indicating it among the top 3 known brands. Other brands that stood out in terms of awareness are: Nescafé, Lavazza, Doncafe, Tchibo. $45 \%$ of all respondents indicated three brands of coffee, $32 \%$ two brands and $19 \%$ one brand. $4 \%$ of respondents indicated no brand.

Table no. 3 The most popular* brands of coffee on the Romanian market

\begin{tabular}{|l|c|c|c|c|}
\hline \multirow{2}{*}{ Brand } & \multicolumn{2}{|c|}{$\begin{array}{c}\text { Share of respondents who indicated a } \\
\text { particular brand among the top three that } \\
\text { come to mind }\end{array}$} & $\begin{array}{c}\text { \% persons who } \\
\text { indicated brand } \\
\text { among the top 3 } \\
\text { known brands in } \\
\text { total number of } \\
\text { respondents }\end{array}$ \\
\cline { 2 - 5 } & $\begin{array}{c}\text { As first } \\
\text { option }\end{array}$ & $\begin{array}{c}\text { As second } \\
\text { option }\end{array}$ & As third option & 68 \\
\hline Jacobs & 38 & 20 & 10 & 43 \\
\hline Nescafé & 15 & 19 & 9 & 34 \\
\hline Lavazza & 17 & 12 & 5 & 19 \\
\hline Doncafé & 12 & 2 & 5 & 15 \\
\hline Tchibo & 4 & 7 & 4 & 8 \\
\hline Fort & 5 & 2 & 1 & $\mathrm{X}$ \\
\hline Other answers & 5 & 15 & 11 & 45 \\
\hline Total & 96 & 77 & 4 & \\
\hline
\end{tabular}

Source: own computation

For tea category, respondents indicated both tea brands that are made in their own household (including herbal) and soft drink brands that contain tea plant. $71 \%$ of respondents indicated a minimum of 1 brand for this category of products and $15 \%$ three brands. Only four brands were indicated by at least five respondents among the top three known brands. In the first places in terms of top of mind awareness lies Lipton (soft drink brand) and Fares (indigenous herbal tea brand). Depending on the number of respondents who have indicated the top three brands that come to mind, Fares brand was surpassed by Lipton.

Table no. 4 The most popular* brands of tea on the Romanian market

\begin{tabular}{|l|c|c|c|c|}
\hline \multirow{2}{*}{ Brand } & \multicolumn{2}{|c|}{$\begin{array}{c}\text { Share of respondents who indicated a particular } \\
\text { brand among the top three that come to mind }\end{array}$} & $\begin{array}{c}\text { \% persons who } \\
\text { indicated brand } \\
\text { among the top 3 } \\
\text { known brands in } \\
\text { total number of } \\
\text { respondents }\end{array}$ \\
\hline Lipton & As first option & $\begin{array}{c}\text { As second } \\
\text { option }\end{array}$ & $\begin{array}{c}\text { As third } \\
\text { option }\end{array}$ & 35 \\
\hline Fares & 21 & 14 & & 25 \\
\hline Nestea & 21 & 3 & 1 & 19 \\
\hline Greenfield & 16 & 3 & 3 & 12 \\
\hline Other answers & 11 & 7 & 11 & $\mathrm{X}$ \\
\hline Total & 71 & 9 & 15 & $\mathrm{X}$ \\
\hline
\end{tabular}

* brands indicated by a minimum 5 respondents.

Source: own computation

Foreign brands Chio and Lay's are detaching for chips and snacks category. On top of mind, they register 52\% (Lay's) and 23\% (Chio), both being nominated by over $60 \%$ of respondents among the top three brands that come to mind. Of all respondents, $36 \%$ indicated a brand, $38 \%$ two brands and $18 \%$ three brands of chips. A share of $8 \%$ didn ${ }^{t}$ remembered any brand in this product category. 
Table no. 5 The most popular* brands of chips and snacks on the Romanian market

\begin{tabular}{|c|c|c|c|c|}
\hline \multirow{2}{*}{ Brand } & \multicolumn{3}{|c|}{$\begin{array}{l}\text { Share of respondents who indicated a } \\
\text { particular brand among the top three that come } \\
\text { to mind }\end{array}$} & \multirow{2}{*}{$\begin{array}{l}\% \text { persons who } \\
\text { indicated brand } \\
\text { among the top } 3 \\
\text { known brands in total } \\
\text { number of } \\
\text { respondents }\end{array}$} \\
\hline & $\begin{array}{l}\text { As first } \\
\text { option }\end{array}$ & $\begin{array}{l}\text { As second } \\
\text { option }\end{array}$ & $\begin{array}{l}\text { As third } \\
\text { option }\end{array}$ & \\
\hline Lay's & 52 & 24 & 5 & 81 \\
\hline Chio & 23 & 30 & 8 & 61 \\
\hline Star & 3 & 5 & 6 & 14 \\
\hline Lotto & 2 & 3 & 4 & 9 \\
\hline Viva & 3 & 1 & 4 & 8 \\
\hline Krax & 3 & 3 & - & 6 \\
\hline Other answers & 6 & 8 & 9 & $\mathrm{X}$ \\
\hline Total & 92 & 74 & 36 & $\mathrm{X}$ \\
\hline
\end{tabular}

Regarding soft drinks, first in the top of mind is occupied by Coca Cola (28\%), followed by: Fanta, Pepsi, Prigat and domestic brand Dorna, with percentages below half of the level recorded by the first brand. From the perspective of the first three brands remembered by the respondents, first in the top are: Coca Cola, Fanta, Pepsi, Sprite, Dorna. A significant share of all respondents - 75\%, nominated three brands, $15 \%$ indicated two brands, and 5\% one brand. 5\% of respondents could not indicate any brand of soft drinks.

Table no. 6 The most popular* brands of soft drinks on the Romanian market

\begin{tabular}{|c|c|c|c|c|}
\hline \multirow{2}{*}{ Brand } & \multicolumn{3}{|c|}{$\begin{array}{l}\text { Share of respondents who indicated a } \\
\text { particular brand among the top three that come } \\
\text { to mind }\end{array}$} & \multirow{2}{*}{$\begin{array}{l}\% \text { persons who } \\
\text { indicated brand } \\
\text { among the top } 3 \\
\text { known brands in total } \\
\text { number of } \\
\text { respondents }\end{array}$} \\
\hline & $\begin{array}{l}\text { As first } \\
\text { option }\end{array}$ & $\begin{array}{l}\text { As second } \\
\text { option }\end{array}$ & $\begin{array}{l}\text { As third } \\
\text { option }\end{array}$ & \\
\hline Coca Cola & 28 & 19 & 5 & 52 \\
\hline Fanta & 13 & 20 & 10 & 43 \\
\hline Pepsi & 12 & 13 & 8 & 33 \\
\hline Sprite & 3 & 4 & 13 & 20 \\
\hline Dorna & 8 & 4 & 3 & 15 \\
\hline Prigat & 9 & 3 & 2 & 14 \\
\hline Cappy & 3 & 6 & 3 & 12 \\
\hline Borsec & - & 2 & 5 & 7 \\
\hline Adria & 4 & - & 1 & 5 \\
\hline Other answers & 15 & 19 & 25 & $\mathrm{X}$ \\
\hline Total & 95 & 90 & 75 & $\mathrm{X}$ \\
\hline
\end{tabular}

In the category of alcoholic beverages, local brands Cotnari and Ciuc hold the top two spots depending on the number of respondents who have nominated among the top three known brands, followed by J \& B, Jack Daniel's, Timişoreana and Ursus (the last two, also local). Regarding the first nomination, we found that in first position lies Jack Daniel's, followed by Ciuc, Cotnari, J \& B and Timişoreana (the last two with the same number of nominations). This product stands out in terms of share, biggest, of those 
who indicated three brands (79\%). Also, $12 \%$ had two nominations, and 5\% just one. $4 \%$ of respondents have not nominated any brand.

Table no. 7 The most popular* brands of alcoholic beverages on the Romanian market

\begin{tabular}{|c|c|c|c|c|}
\hline \multirow{2}{*}{ Brand } & \multicolumn{3}{|c|}{$\begin{array}{l}\text { Share of respondents who indicated a } \\
\text { particular brand among the top three that come } \\
\text { to mind }\end{array}$} & \multirow{2}{*}{$\begin{array}{l}\text { \% persons who } \\
\text { indicated brand } \\
\text { among the top } 3 \\
\text { known brands in total } \\
\text { number of } \\
\text { respondents }\end{array}$} \\
\hline & $\begin{array}{l}\text { As first } \\
\text { option }\end{array}$ & $\begin{array}{l}\text { As second } \\
\text { option }\end{array}$ & $\begin{array}{l}\text { As third } \\
\text { option }\end{array}$ & \\
\hline Cotnari & 11 & 7 & 8 & 26 \\
\hline Ciuc & 12 & 10 & 3 & 25 \\
\hline $\mathrm{J} \& \mathrm{~B}$ & 7 & 8 & 4 & 19 \\
\hline Jack Daniel's & 13 & 3 & 3 & 19 \\
\hline Timişoreana & 7 & 10 & 2 & 19 \\
\hline Ursus & 6 & 9 & 4 & 19 \\
\hline Cricova & 4 & 2 & 7 & 13 \\
\hline Bucegi & 6 & 2 & 4 & 12 \\
\hline Noroc & 3 & 4 & 5 & 12 \\
\hline Bergenbier & 1 & 4 & 2 & 7 \\
\hline Ciucaş & 3 & 2 & 2 & 7 \\
\hline Heineken & 4 & 1 & 2 & 7 \\
\hline Tuborg & 2 & 1 & 3 & 6 \\
\hline Absolut Vodka & - & 4 & 2 & 6 \\
\hline Angelli & - & 3 & 3 & 6 \\
\hline Alexandrion & 1 & - & 4 & 5 \\
\hline Other answers & 16 & 21 & 21 & $\mathrm{X}$ \\
\hline Total & 96 & 91 & 79 & $\mathrm{X}$ \\
\hline
\end{tabular}

* brands indicated by a minimum 5 respondents.

Source: own computation

\section{Conclusions}

The results of research conducted among students of the Faculty of Economic Sciences of the Vasile Alecsandri University of Bacau on the awareness of the brands of festive food products, show that the brands with the largest shares in terms of the indicator top of mind in the examined sample are: Milka, both in the case of chocolate (48\%) and other sweets (14\%), Jacobs (38\%) for coffee, Lipton and Fares (both 21\%) for tea, Lay's for chips and snacks, Coca Cola (28\%) for soft drink and Jack Daniel's (13\%) for alcoholic beverages. Considering the first three nominations made by the respondents for each category of products, same brands are prevailing, except Fares brand that, from this viewpoint, was surpassed by Lipton.

The issues addressed by this study may be broadened, conclusions drawn could be checked at the level of representative samples of the different collectivities. Also, starting from the brands which enjoy the highest awareness, one can continue to evaluate and study the other attributes that measure their performance.

\section{References}

Dătculescu, P. (2012), Cercetarea practică de marketing, Editura Brandbuilders Grup, București.

Kumar V., Aaker, D.A., Day G.S. (1999), Essentials of Marketing research, John Wiley $\&$ Sons, Inc., New York Chichester Weinheim Brisbane Singapore Toronto. 
Lehmann, Donald R., Sunil Gupta, Joel H. Steckel (1998), Marketing research, Addison - Wesley Educational Publishers Inc.

Manole, V., Stoian M., Ion, R.A. (2003), Agromarketing, Ediţia a II-a, Editura ASE, Bucureşti.

Marian, C., (2016), Dicţionar de agromarketing, Editura Tribuna Economică, Bucureşti.

Peter, J.P. \& Olson, J.C. (2008), Consumer Behavior\& Marketing Strategy, International Edition, McGraw-Hill/Irwin.

Pike, S. (2008), Destination Marketing: An Integrated Marketing Communication Approach, Elsevier.

Săndulescu L. (2015, September, 18), Top 100 cele mai puternice branduri romanesti, Revista Biz available at http://www.revistabiz.ro/top-100-cele-mai-puternicebranduri-romanesti/.

Ţimiraş, L. (2016), Young People's Preferences For Romanian Agro Alimentary Goods, Studies and Scientific Researches. Economics Edition, Special Issue, available at: http://sceco.ub.ro/index.php/SCECO/article/view/353.

Voinea, L (2013), Calitate şi securitate alimentară. Reorientări în comportamentul alimentar al consumatorului modern, Editura ASE.

Zaharia R.M. (2003), Notorietate, in Florescu, C., Mâlcomete P., \& Pop, N.Al. Pop (coord.), Marketing. Dicţionar explicativ, Editura Economică, Bucureşti.

Revista Piaţa (2008, Iunie, 21), Brandul romanesc fata cu globalizarea, available at: http://www.revista-piata.ro/Marci_romanesti-id168.html. 